\title{
Antimicrobial Activity of Single-Walled Carbon Nanotubes (Swcnts) Against Marine Bacteria Staphylococcus aureus
}

\author{
Majed Ahmed Al-Shaeri* \\ Department of Biologicals Sciences, Faculty of Sciences, King Abdulaziz University, Jeddah, Saudi Arabia \\ *Corresponding Author: Majed Ahmed Al-Shaeri, Department of Biologicals Sciences, Faculty of Sciences, King Abdulaziz University, \\ Jeddah, Saudi Arabia.
}

Received: November 18, 2019; Published: November 20, 2019

DOI: $10.31080 /$ ASPS.2019.03.0442

\begin{abstract}
Nanotechnology is a global investment that makes the structures, materials, devices, and the systems whose size ranges from approximately $1 \mathrm{~nm}$ to $100 \mathrm{~nm}$. Based on physiochemical properties of SWCNTs, there are possible adverse effects of their presence on biological systems by using SWCNTs as biosensors or drug delivery. The increasing use of SWCNTs through anthropogenic activity is maybe indicator to increase the release it into the environment. The antibacterial activity and mechanism of SWCNTs (Ag- on Staphylococcus aureus ATCC 6538P were investigated. S. aureus was expoede to nominal concentrion of SWCNTs (1.5, 2.5, 5, 10 and $20 \mu \mathrm{g} / \mathrm{ml}$ ). The experiment results showed that, 1.5 and $2.520 \mu \mathrm{g} / \mathrm{ml}$ did not either effect on $S$. aureus growth inhibition and enzymatic activity. While the growth of $S$. aureus was inhabited when exposed to 5, 10 and $20 \mu \mathrm{g} / \mathrm{ml}$ SWCNTs, and then, the enzymatic activity of respiratory chain dehydrogenase was significantly decreased. It concludes that, SWCNTs are able to inhibit the bacterial cells growth.
\end{abstract}

Keywords: Staphylococcus aureus; Single-Walled

\section{Introduction}

The spread production of nanometre-diameter particles (NMs, NPs) may increase their inhalation through air borne, which may cause effect on biological system. A lot of attention by scientists, practically to understand the toxicity effect of nanomaterials (NMs) on environmental health, small numbers are known about possible effect of carbon nanotubes (CNTs) on aquatic organisms, and also their potential environmental risk and fate are still unknown. In generals, the toxicological research of carbon nanomaterials (CNTs) on aquatic biota in vivo and single walled carbon nanotubes (SWCNs) in particular are essentially need to be well understand, probably because of the lack information mechanisms of their complicated physiochemical properties behavior (surface charge, stabilization and agglomeration) in water. In marine environment, aquatic biota can take up Carbon nanotubes, Staphylo- coccus aureus (S. aureus) is disrtibuted in varied habitats, starting from humans to sea mammals [1]. Although many species of S. aureus are harmless but some pathogenic species are always a threat, thus there is a need for discovery of new antimicrobial drugs [2]. Many different antibiotics and herbal medicines have been used to combat the major problem of antimicrobial resistance but it's not completely eliminated yet [3]. There are various potential virulence factors such as efflux, quorum sensing and antibody-mediated immune responses which play a major role in development of resistance against antibiotics [4]. Apart from this the strains of $S$. aureus has multiple mechanisms for evading both innate immunity mediated by polymorphonuclear leukocytes and the immunity induced by both T cells and B cells [5]. The organism also expresses a number of super antigen toxins and membrane-damaging toxins that can cause symptoms of septic shock and the tissue damage re- 
spectively [6]. Few of the virulence factors are as a result of variations in gene expression by some of the genes located on mobile genetic elements called pathogenicity islands [7].

Research work is being carried out on both beneficial and harmful effects of single walled carbon nanotubes (SWCNTs) on the biological environment is amongst the most emerging fields in the world of biomedical applications of nanoparticles [8]. The exceptional chemical and physical properties of SWCNTs are responsible for these nanostructures fascinating is their multifaceted behavior towards human cellular [9]. The possibility for tuning the properties of these nanoparticles through chemical modifications and their capability to be internalized into various cellular organelles and also its positive interaction with cellular systems such as neuronal and bone cells [10]. Nanomaterials with required size, structure and shape are the major building blocks in various electronic, magnetic and biomedical applications [11]. Thus nanomaterials for therapeutic and diagnostic uses.

\section{Materials and Methods}

Materials

A SWCNT stock (1 mg L1 ; Sigma-Aldrich; catalog 704121; manufacturer's specifications, diameter $1.1 \mathrm{~nm}$ - length 0.5-100 mm; G/D Ratio: $\geq 15$ (Raman $633 \mathrm{~nm}$ ); $\geq 90 \%$ carbon basis $(\geq 77 \%$ as carbon nanotubes) was prepared in distilled water using $0.02 \%$ Suwannee River natural organic matter. Prior to use, SWCNT stock was dispersed using an ultrasonic bath for 2 hours.

Microbial strains and media

The Staphylococcus aureus ATCC6538P strain was purchased from American Type Culture Collection (ATCC). The bacteria were sub cultured and Mueller-Hinton medium pH7.4 $\pm 0.2\left(25^{\circ} \mathrm{C}\right)$ (purchased from Sigma-Aldrich; contains: $2.0 \mathrm{~g} / \mathrm{l}$ of beef extract, 1.5 $\mathrm{g} / \mathrm{l}$ soluble starch, and $17.5 \mathrm{~g} / \mathrm{l}$ of casein hydrolysate. The medium was used for testing the efficacy of single walled carbon nanotubes (SWCNTs) in liquid culture. Simultaneously the CNTs were tested for the antibacterial activity against $S$. aureus on Muller Hinton agar plates at various concentrations. The bacteria were then subjected for centrifugation at $6000 \mathrm{rpm}$ for 10 minutes. After centrifugation the pellets were washed 3 times using saline. This bacterial broth was then diluted using saline and adjusted to 0.5 McFarland units which is at optical density 0.08 to 0.1 O.D and the bacterial count is estimated to be $10^{7} \mathrm{CFU}$ per $\mathrm{ml}[12]$.
1. Agar well assay: The CNTs were subjected to Muller Hinton agar plates and bacteria were spread on agar plates, $6 \mathrm{~mm}$ wells were bored on agar and the CNTs suspension was poured into it.

2. Liquid Broth assay: $1 \mathrm{ml}$ of bacteria with a concentration of about $10^{7}$ cells are poured into multiple tubes and different concentrations of CNTs were poured in the tubes with bacteria ranging from $5 \mu \mathrm{g} / \mathrm{ml}$ to $20 \mu \mathrm{g} / \mathrm{ml}$. Then positive and negative controls were set with only bacteria and only nanotubes in separate tubes. These tubes were then kept in a shaking incubator at $200 \mathrm{rpm}$ and $37^{\circ} \mathrm{C}$ for 2 hours. After incubation the Optical density of each tube was measured in a spectrophotometer at $600 \mathrm{~nm}$. The bacteria and control tubes were diluted and cultured on separate petri plates for colony counting assay.

Minimum inhibitory concentration and minimum bactericidal concentration of SWCNTs

To examine the growth curves effect, Staphylococcus aureus were exposed to SWCNTs at nominal concertations $(1.5,2.5,5,10$, and $20 \mu \mathrm{g} / \mathrm{ml}$ ) for five days respectively. Medium, SWCNTs at different connections, and $S$. aureus cells were placed separately to $20 \mathrm{ml}$ cultures, resulting in final concentrations of SWCNTs from 0 to 20 $\mu \mathrm{g} / \mathrm{ml}$ and $10^{7} \mathrm{cfu} / \mathrm{ml}$ S. aureus cells. The incubating and determining methods were according to [13].

Effect of SWCNTs on enzymatic activity of respiratory chain dehydrogenase

As a negative control, $S$. aureus cells were boiled for 15 to 20 minutes to gain completely inactivated enzymes, while the $S$. aureus cells that were not boiled were considered as positive control, which their enzymes remained activity. Dehydrogenase activity was determined according to the iodonitrotetrazolium chloride method [13-15].

\section{Results}

\section{Growth of S. aureus exposed to SWCNTs}

Antibacterial activity of SWCNTs was evaluated by using Agar well assay and Liquid broth assay. SWCNTs were used at different concentrations ranging from 5 to $20 \mu \mathrm{g} / \mathrm{ml}$ against. when Staphylococcus aureus exposed to of 1.25 and $2.5 \mu \mathrm{g} / \mathrm{ml}$ SWCNTS did not show effect on their growth over 5 days, however, the 5,10 and $20 \mu \mathrm{g} / \mathrm{ml}$ of SWCNTS did show effect on cells growth significantly 
above that of the control group ( $\mathrm{p}=0.991)$. The $s$. aureus growth at 5,10 and $20 \mu \mathrm{g} / \mathrm{ml}$ concentrations of SWCNTS was clearly shown inhabited by day 3 (Figure 1).

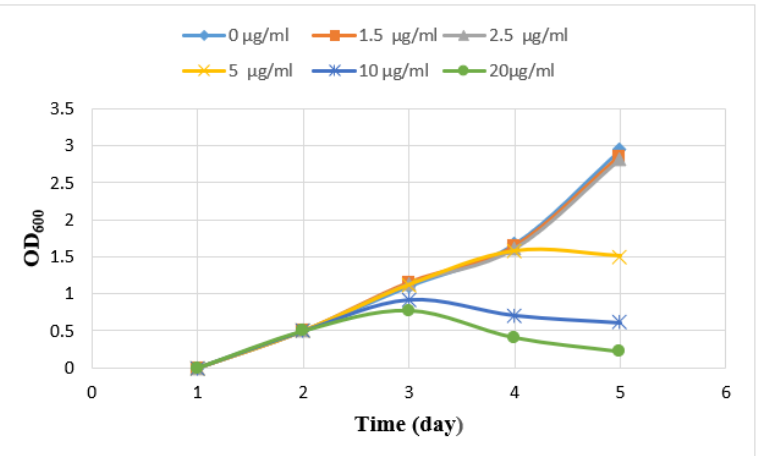

Figure 1: Growth curves of $S$. aureus cells exposed to different concentrations of Ag-NPs.

Effect of Ag-NPs on enzymatic activity of respiratory chain dehydrogenase

The respiratory chain dehydrogenase activity (RCD) was shown increased in a positive control cells incubation in $30 \mathrm{~min}$ utes. $2.5 \mu \mathrm{g} / \mathrm{ml}$ of SWCNTs was shown as high as positive control in the enzymatic activity of bacterial cells (Figure 2), however, there is a significant decrease in the enzymatic activity of bacterial cells at 5 and $20 \mu \mathrm{g} / \mathrm{ml} \mathrm{SWCNTs.} \mathrm{It} \mathrm{suggested} \mathrm{that} 2.5 \mu \mathrm{g} / \mathrm{ml} \mathrm{SWCNTs}$ did not inhibit the $10^{7} \mathrm{cfu} / \mathrm{ml}$ S. aureus cells. But in the enzymatic activity of bacterial cells exposed to $50 \mu \mathrm{g} / \mathrm{ml}$ SWCNTs did incur inhibition significantly above that of the positive control group ( $\mathrm{p}$ $=0.996)$ and $2.5 \mu \mathrm{g} / \mathrm{ml} \mathrm{SWCNTs}(\mathrm{p}=0.984)$.

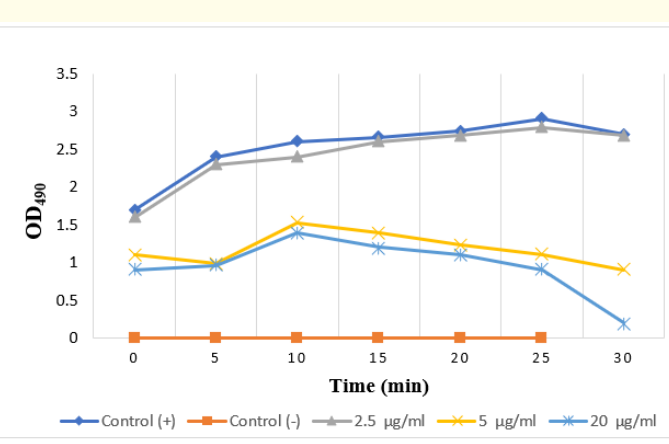

Figure 2: Effect of SWCNTs on respiration chain dehydrogenases in S. aureus cells. Error bars represent standard deviations of duplicate incubations. The negative and positive controls represent the boiled and not boiled $S$. aureus cells respectively.

\section{Data analysis}

The statistical analysis was performed with Sigma Stat. Differences between treatments were analysed with a One Way ANOVA, followed by a Tukey all pairwise multiple comparisons procedure (Sparks, 2000).

\section{Discussion}

The antibacterial activity of $5 \mu \mathrm{g} / \mathrm{ml}$ to $20 \mu \mathrm{g} / \mathrm{ml}$ of SWCNTs against Staphylococcus aureus bacteria was observed and found to be effective. In one of the studies carried out by Seo., et al. 2014, the silver coupled carbon nanotubes were effective against Methylobacterium spp. CNTs are well known in possessing an excellent conductivity with strong dielectric breakdown capacity and hold an outstanding field electron emission properties [16]. The Marine Species of Staphylococcus aureus is found to be inhibited at high concentrations 5, 10 and $20 \mu \mathrm{g} / \mathrm{ml}$ SWCNTs. At this high concentrations of SWCNTs the highest number of bacteria were inhibited leading to increase in the density of the solution and simultaneously the optical density. For the first time in 2007, Kang., et al. have reported the study about antimicrobial activity of single wall carbon nanotubes (SWCNTs) against bacterial species E. coli [17]. E. coli cells and $S$ aureus were effecte on their growth inhibiotn and RCD when they exposed to Ag-NPs $[13,18]$. Similarly, in the presence study The RCD was effected by SWCNTs at high concentrations (5, $10,20 \mu \mathrm{g} / \mathrm{ml}$ ), SWCNTs showed to destroy the RCD and accordingly inhibited the respiration to interfere with normal growth and metabolism of Staphylococcus aureus cells.

\section{Conclusion}

In conclusion, the above experiments demonstrated a possible antibacterial process of SWCNTs on S. aureus cells: SWCNTs maybe caused cell wall breakage, and then internalized into the bacteria cell. Ag-NPs internalized into S. aureus cells and caused DNA damage [17,18-21]. SWNTs can exhibit strong antimicrobial activity. Our finding suggests that single walled carbon nanotubes can be useful as building blocks for antimicrobial product.

\section{Bibliography}

1. Monecke S Gavier-Widé D., et al. "Diversity of Staphylococcus aureus Isolates in European Wildlife". PLoS One 11 (2016): e0168433.

2. Lowy FD. "Antimicrobial resistance: the example of Staphylococcus aureus". Journal of Clinical Investigation 111.9 (2003): 1265-1273.

3. Li B and Webster TJ. "Bacteria antibiotic resistance: New challenges and opportunities for implant-associated orthopedic infections". Journal of Orthopaedic Research 36.1 (2017): 22-32. 
4. Lacey KA., et al. "The Role of Staphylococcus aureus Virulence Factors in Skin Infection and Their Potential as Vaccine Antigens". Pathogens 5.1 (2016): 22.

5. Thammavongsa V., et al. "Staphylococcal manipulation of host immune responses". Nature Reviews Microbiology 13.9 (2015): 529-543.

6. Otto M. "Staphylococcus aureus toxins". Current Opinion in Microbiology 17 (2013): 32-37.

7. Malachowa N and DeLeo FR. "Mobile genetic elements of Staphylococcus aureus". Cellular and Molecular Life Sciences 67.18 (2010): 3057-3071.

8. Jha RK., et al. "An emerging interface between life science and nanotechnology: present status and prospects of reproductive healthcare aided by nano-biotechnology". Nanotechnology Reviews 5 (2014): 10.

9. Jeevanandam J., et al. "Review on nanoparticles and nanostructured materials: History, sources, toxicity, and regulations". Beilstein Journal of Nanotechnology 9 (2018): 1050 - 1074.

10. Panzarini E., et al. "Intracellular Transport of Silver and Gold Nanoparticles and Biological Responses: An Update". International Journal of Molecular Sciences 19 (2018): 1305.

11. Ramos AP., et al. "Biomedical applications of nanotechnology". Biophysical Reviews 9.2 (2017): 79-89.

12. Berdjeb L., et al. "Contrasting responses of marine bacterial strains exposed to carboxylated single-walled carbon nanotubes". Aquatic Toxicology 144-145C (2013): 230-241.

13. Li WR., et al. "Antibacterial activity and mechanism of silver nanoparticles on Escherichia coli". Applied Microbiology and Biotechnology 85 (2010): 1115-1122.

14. Iturriaga R., et al. "Detection of respiratory enzyme activity in Giardia cysts and Cryptosporidium oocysts using redox dyes and immunofluorescence techniques". Journal of Microbiological Methods 46 (2001):19-28.

15. Kim KJ., et al. "Antifungal activity and mode of action of silver nanoparticles on Candida albicans". Biometals 22 (2009): 235242.

16. Smotlacha J and Pincak R. "Electronic Properties of Carbon Nanostructures". Ar Xiv (2016).
17. Kang S., et al. "Single-walled carbon nanotubes exhibit strong antimicrobial activity". Langmuir 23 (2007): 8670-8673.

18. Li., et al. "Antibacterial effect of silver nanoparticles on Staphylococcus aureus". Biometals 24.1 (2011): 135-141.

19. Al-Shaeri MAM., et al. "Green algae interacting with singlewalled carbon nanotubes affect the feeding behaviour of mussels, mitigating nanotube toxicity". In SETAC Europe Meeting, Basel, Switzerland, Basel (2014):11-15.

20. Al-Shaeri., et al. "Potentiating toxicological interaction of single-walled carbon nanotubes with dissolved metals". Environmental Toxicology and Chemistry 32.12 (2013): 2701-2710.

21. Templeton RC., et al. "Life-cycle effects of single-walled carbon nanotubes (SWNTs) on an estuarine meiobenthic copepod". Environmental Science and Technology 40.23 (2006): 73877393.

\section{Volume 3 Issue 12 December 2019}

(C) All rights are reserved by Majed Ahmed Al-Shaeri. 